\title{
Analysis of stress and anxiety in university students to identify correlated factors
}

\section{Análisis del estrés y ansiedad en estudiantes universitarios para identificar factores correlacionados}

\author{
LOBATO-BAEZ, Mariana $\dagger^{* 1}$, MORALES-ROSALES, Luis Alberto ${ }^{2}$, ALGREDO-BADILLO, \\ Ignacio $^{3}$ and RODRÍGUEZ-RANGEL, Héctor ${ }^{4}$ \\ ${ }^{1}$ Instituto Tecnológico Superior de Libres, Camino Real S/N, Barrio de Tétela, C.P. 73780. Libres, Puebla, México. \\ ${ }^{2}$ Conacyt-Universidad Michoacana de San Nicolás de Hidalgo, Avenida Francisco J. Múgica S/N Ciudad Universitaria \\ Morelia, C.P. 58030 Michoacán, México. \\ ${ }^{3}$ Instituto de Astrofísica Óptica y Electrónica, Luis Enrique Erro \# 1, C.P. 72840, Tonantzintla, Puebla, México. \\ ${ }^{4}$ Instituto Tecnológico de Culiacán, Juan de Dios Batiz No.310 pte., Col Guadalupe, C.P. 80220 Culiacán Rosales, Sin.
}

ID $1^{\text {st }}$ Author: Mariana, Lobato-Baez / ORC ID: 0000-0002-2607-2032, CVU CONACYT ID: 310467

ID $1^{\text {st }}$ Co-author: Luis Alberto, Morales-Rosales / ORC ID: 0000-0002-4753-9375, CVU CONACYT ID: 48253

ID $2^{\text {nd }}$ Co-author: Ignacio, Algredo-Badillo / ORC ID: 0000-0002-4748-3500, CVU CONACYT ID: 41716

ID $3^{\text {rd }}$ Co-author: Hector, Rodriguez-Rangel / ORC ID: 0000-0003-4999-3472, CVU CONACYT ID: 219230

DOI: $10.35429 / J E T .2021 .13 .5 .10 .19$

Received March 14, 2021; Accepted June 29, 2021

\begin{abstract}
In the present study, we analyze the stress, anxiety, state, and academic features of 478 higher-level students. We identify the correlated factors using multiple linear regression and Pearson's correlation coefficients. We use the SISCO and STAI instruments to measure academic stress at the anxiety level. We determine that the most representative stressors in students are the teachers' evaluations with $31 \%$ as almost always and $11 \%$ as always, physical reactions such as drowsiness or need to sleep $31 \%$ as almost always, $12 \%$ always. Besides, reactions of depression and sadness show a 9\% as almost always, $9 \%$ as always. Behavioral and coping reactions show 9\% almost always and 9\% always. The most outstanding anxiety reactions in the present research revealed that $48 \%$ of the students never feel calm, $40 \%$ never have happiness like others, $41 \%$ are never satisfied or comfortable with themselves. Some psychological changes related to stress and anxiety are closely linked to the suicide rate, derived from the fact that the generated uncertainty becomes a potential source of stress and vulnerability to depressive or anxiety disorders.
\end{abstract}

Academic stress, Anxiety, Multiple linear regression

\begin{abstract}
Resumen
En el presente estudio se analizó el nivel de estrés, ansiedad, estado y rasgo académico que presentan 478 alumnos de nivel superior, identificando los factores correlacionados mediante regresión lineal múltiple y el coeficiente de correlación de Pearson. Para medir el estrés académico a nivel de ansiedad se hizo uso de los instrumentos SISCO y STAI, determinando que los estresores más representativos en los estudiantes son las evaluaciones con los profesores con $31 \%$ casi siempre y $11 \%$ siempre, reacciones físicas que enfrentan tales como somnolencia o necesidad de dormir $31 \%$ casi siempre, $12 \%$ siempre como reacciones de depresión y tristeza $9 \%$ casi siempre $9 \%$ siempre reacciones comportamentales y de afrontamiento muestran el $9 \%$ casi siempre y $9 \%$ siempre. Las reacciones de ansiedad más destacadas en la presente investigación son que el $48 \%$ de los estudiantes nunca tienen sensación de calma $40 \%$ nunca tienen felicidad como otros, $41 \%$ nunca están conformes ni a gusto con ellos mismos. Algunos cambios psicológicos relacionados con el estrés y la ansiedad se encuentran estrechamente ligados a la tasa de suicidio, derivado a que la incertidumbre que se genera se convierte en una fuente potencial de estrés y vulnerabilidad de trastorno depresivo o ansioso.
\end{abstract}

Estrés académico, Ansiedad, Regresión lineal múltiple

Citation: LOBATO-BAEZ, Mariana, MORALES-ROSALES, Luis Alberto, ALGREDO-BADILLO, Ignacio and RODRÍGUEZ-RANGEL, Héctor. Analysis of stress and anxiety in university students to identify correlated factors. Journal Educational Theory. 2021. 5-13: 10-19

\footnotetext{
* Correspondence to Author (e-mail: mariana.lobato@ upaep.edu.mx)

$\dagger$ Researcher contributing as first author.
} 


\section{Introduction}

Academic stress and anxiety usually describe a wide range of experiences: nervousness, physiological activation, tension, fatigue, overwhelm, restlessness, and other similar sensations, such as excessive school pressure (Águila, Castillo, de la Guardia and Achon, 2015: 167). The inclusion of stress as part of daily life in the 21 st century has become present in different areas (Collazo, Rodríguez, 2011 \& Martínez, 2010), and it is considered a social problem. However, academic stress is a topic that has not received enough attention in research (Monzón, 2017: 87).

The accelerated student's life throughout the learning process includes diverse and complex activities such as homework, exhibitions, assignments, exams, commitments, and outings with friends, causing an overload of events, resulting in academic stress, an action that affects the intellectual, physical and psychological environment (Sarubbi \& Castaldo, 2013: 291, 293).

Several kinds of research show that from preschool to postgraduate college education, when a person is in a learning period, they experience academic stress. It occurs both for individual study and in the classroom.

Diverse authors have examined factors that allow for highlighting academic stress (Mendoza, Ortega, Quevedo, Martínez, Aguilar, Hernández, 2010: 38), such as the overload of homework and schoolwork, limited time to do the work (Martin, 2007: 95), overwork (Depraect, Decuir, Castro, \& Salazar, 2017: 95), application of examinations, activities or tasks that are contradictory to each other, little practice of the classes (Cabanach, Fernández, González, Freire, 2010, Polo, 1996 \& Celis, 2001 Bustamante, Cabrera, Alarcón, Monge, 2001), high academic load expressed in the number of courses both face-to-face and/or not face-toface, the time they must dedicate to study (Lazarus, 1986) (Guadarrama, Mendoza, Veytia, Serrano \& Ruíz, 2012), socioeconomic status, work and task overload that contributes significantly to explain the trigger for academic stress and success in academic performance in those students who control and handle in a reasonable tone the stress.
On the subject of anxiety, the research of (Saranson, 1990) describes that it depends on factors such as the degree of demands (difficulty of the task), the ability to control the effects that interfere with ourself concerning about anticipating danger, availability and use of adequate instrumental resources (Gutiérrez, 1996), as well as academic overload and lack of time to complete academic activities (Polo, Hernandez \& Pozo, 1996).

A series of changes characterize emerging adulthood in the university. Among those related to eating habits, Risky Eating Behaviors (CAR) are acquired, which are associated with symptoms of anxiety, depression, and stress, before which social support can act as a protective factor (EscandónNagel, 2021).

Anxiety during the exam is positively related to the search for social support (Stöber, 2004) (Putwain, Connors, Symes, \& Douglas, 2012). On the contrary, not living with the family during the course can be an associated stressor to the risk of anxiety, which is also confirmed in a study carried out with Iranian students (Makaremi, 2000).

Author such as (Jara, Velarde, Gordillo, Guerra, León, Arroyo, \& Figueroa, 2018: 196) describe that the main cause is the lack of study habits and strategies. On the other hand, (Medina, 2012: 65,66) indicates that environmental stressors and individual stressors impact the physical, psychological, social, and emotional development of the individual. Besides, the form of teaching by some teachers, the academic model, and evaluation forms. Furthermore, (Laredo, Huante, Hernández, Moran, \& Loeza, 2014: 188) mention that the exams and how students prepare to carry them out detonate stress.

(Sarubbi \& Castaldo, 2013: 293) explains that social environment, urban or rural origin, home formation, lack of commitment, motivation, interest and time invested in personal study, and class attendance are the factors that generate stress in students. 
Despite the various studies carried out, multiple studies have shown that coping with stress is a preventive measure, describing different strategies:

1. Acceptance, such as the attitude of respecting and loving oneself and towards others.

2. Self-analysis, such as reflection on one's thoughts, motivations, feelings, behavior, recognizing self-responsibility to act finally.

3. Social support when people go and seek others for emotional support.

4. Self-control, such as the ability to control feelings, their reactions (lazarus, 1986). However, (guadarrama, márquez, mendoza, veytia, serrano, luis \& ruíz, 2012) refer to the fact that, if the university student decides to adapt and face those factors that he perceives as a cause of stress, he can satisfactorily resolve the day to day in the school.

One of the critical aspects to highlight is that suicide has become a severe public health problem due to its increase in young people from 15 to 24 years due to stress and anxiety in recent years. An estimated one million people committed suicide in 2000, making suicide one of the top ten causes of death in many countries. 10 to 20 times more people attempted suicide, and the actual numbers are even inferred to be higher. Although suicide rates vary by demographic category, in the last 50 years, they have increased by approximately $60 \%$ worldwide (WHO, 2006). In Mexico, October 2014 (PAHO / WHO).

About 65,000 people kill themselves each year, according to the existing suicide data in Mexico. In general, these show an increasing trend in the long term. In 1950 the rates were close to 1.5 suicides per 100,000 inhabitants. By 2008, these rates had multiplied by three and had already reached 4.8 suicides per 100,000 inhabitants. However, it is essential to remark that in the 1960s, suicide rates decreased and arose again after 1970, an upward trend maintained to date.
Hence, in the present paper, we analyze the student perception about factors that generate stress and anxiety when studying engineering careers at the undergraduate level. In this sense, the purpose of this research is to identify the correlated factors between the causes of anxiety and stress and know-how students cope with them.

\section{Materials and methods}

\section{Sample selection}

We collected the data through an intentional sampling of a Higher Education Institution that attends students from different areas, both rural and urban areas belonging to Libres, Puebla, Mexico. Four hundred seventy-eight students between the ages of 18 and 29 were surveyed, of which 285 were men and 193 women, distributed in four semesters of the Instituto Tecnológico Superior de Libres (ITSL): a) semester 1 with $\mathrm{n}=174$, b) semester 2 with $\mathrm{n}=105$, c) semester 3 with $\mathrm{n}=113$, and d) semester 4 with $n=86$.

\section{Research instruments}

For the present research, the SISCO Academic Stress Inventory (Macias, 2007) was used to recognize the characteristics of stress that usually accompany students of upper secondary, higher, and postgraduate education during their study (Macias, 2007: 90-93).

We use the State-Trait Anxiety Inventory instrument (STAI) proposed by (Guillén \& Buela, 2015; 294) to determine the degree of anxiety of the 478 students, allowing us to measure the level of state-anxiety and trait anxiety.

Currently, the STAI questionnaire is widely used to measure the level of anxiety in different clinical contexts (Venderbos, Van Den Bergh, Roobol, Schröder, Essink-Bot, Bangma $\&$ 2015) and in populations of university students (Fonseca, Paino, Sierra, Baigrie ., Lemos-Giráldez, Muniz, 2012 \& Pottier, Hardouin, Dejoie, Bonnaud, Le Loupp \& Planchon 2011). The STAI has shown high reliability and validity (Gross, 2007). 
We developed two identical versions of the instruments, a mobile version (via Android, PHP with a Postgres database) and a printed version to facilitate data collection.

Using Cron Bach's Alpha, we obtain a reliability value of 0.826 for the SISCO instrument and 0.721 for the STAI instrument, allowing us to exhibit an adequate indicator to carry out the formal analysis of the data collected. The Kaiser-Meyer-Olkin (KMO) overall mean was 0.823 for the SISCO instrument and 0.888 for the STAI instrument.

\section{Procedure}

Once we selected the instruments, their application was at the Instituto Tecnológico Superior de Libres Puebla, Mexico. According to the rules for scientific research, we submitted a prior authorization to the institute manager to carry out the survey.

For this purpose, we established personal contact with the academic director. After that, we applied the instruments with the consent of the students and directors. We carried out the applications of the instruments in classrooms with a maximum time of 25 minutes per group. Then, we carry out the data analysis with multiple linear regression and pearson's correlation coefficient.

\section{Analysis and results}

We analyze descriptive statistics regarding stressors, physical reactions, psychological reactions, behavioral reactions, and coping reactions in the SISCO instrument.

Table 1 shows the response percentage for each item with its respective indicator considering as triggers of stress the evaluations of the teachers, overload of tasks, work, reactions of drowsiness, need to sleep, depression, sadness, and concentration problems.

\begin{tabular}{|c|c|c|c|c|c|}
\hline \multicolumn{6}{|c|}{ Stressors } \\
\hline Item & Never & Rarely & Sometimes & $\begin{array}{r}\text { Almost } \\
\text { always }\end{array}$ & Always \\
\hline Competition with peers & $21 \%$ & $24 \%$ & $44 \%$ & $7 \%$ & $4 \%$ \\
\hline $\begin{array}{l}\text { Overload of homework } \\
\text { and school work }\end{array}$ & $7 \%$ & $14 \%$ & $39 \%$ & $31 \%$ & $9 \%$ \\
\hline $\begin{array}{l}\text { Teacher personality and } \\
\text { character }\end{array}$ & $10 \%$ & $31 \%$ & $30 \%$ & $22 \%$ & $7 \%$ \\
\hline Teacher evaluations & $6 \%$ & $17 \%$ & $35 \%$ & $31 \%$ & $11 \%$ \\
\hline $\begin{array}{l}\text { Type of work requested } \\
\text { by teachers }\end{array}$ & $3 \%$ & $26 \%$ & $46 \%$ & $16 \%$ & $9 \%$ \\
\hline $\begin{array}{l}\text { Not understanding the } \\
\text { issues }\end{array}$ & $9 \%$ & $30 \%$ & $44 \%$ & $12 \%$ & $5 \%$ \\
\hline Class participation & $16 \%$ & $24 \%$ & $39 \%$ & $15 \%$ & $6 \%$ \\
\hline Limited time to do jobs & $5 \%$ & $18 \%$ & $49 \%$ & $19 \%$ & $9 \%$ \\
\hline \multicolumn{6}{|c|}{ Physical Reactions } \\
\hline Sleep disorders & $21 \%$ & $36 \%$ & $26 \%$ & $12 \%$ & $5 \%$ \\
\hline Chronic fatigue & $17 \%$ & $25 \%$ & $41 \%$ & $16 \%$ & $1 \%$ \\
\hline Headaches or migraine & $18 \%$ & $35 \%$ & $30 \%$ & $15 \%$ & $2 \%$ \\
\hline Digestion problems & $18 \%$ & $35 \%$ & $30 \%$ & $15 \%$ & $2 \%$ \\
\hline To bite nails & $29 \%$ & $18 \%$ & $18 \%$ & $28 \%$ & $7 \%$ \\
\hline $\begin{array}{l}\text { Drowsiness or need to } \\
\text { sleep }\end{array}$ & $12 \%$ & $13 \%$ & $32 \%$ & $31 \%$ & $12 \%$ \\
\hline \multicolumn{6}{|c|}{ Psychological reactions } \\
\hline Restlessness & $13 \%$ & $23 \%$ & $43 \%$ & $14 \%$ & $7 \%$ \\
\hline Depression sadness & $23 \%$ & $28 \%$ & $31 \%$ & $9 \%$ & $9 \%$ \\
\hline Anxiety & $18 \%$ & $28 \%$ & $40 \%$ & $12 \%$ & $2 \%$ \\
\hline Concentration problems & $9 \%$ & $22 \%$ & $48 \%$ & $14 \%$ & $7 \%$ \\
\hline $\begin{array}{ll}\begin{array}{l}\text { Aggression } \\
\text { irritability }\end{array} & \text { or } \\
\end{array}$ & $25 \%$ & $27 \%$ & $35 \%$ & $12 \%$ & $1 \%$ \\
\hline \multicolumn{6}{|c|}{ Behavioral reactions } \\
\hline Polemicize or argue & $28 \%$ & $24 \%$ & $44 \%$ & $7 \%$ & $4 \%$ \\
\hline Isolation from others & $23 \%$ & $48 \%$ & $18 \%$ & $8 \%$ & $3 \%$ \\
\hline Reluctance & $16 \%$ & $36 \%$ & $32 \%$ & $15 \%$ & $1 \%$ \\
\hline $\begin{array}{l}\text { Increase or decrease in } \\
\text { food consumption }\end{array}$ & $20 \%$ & $28 \%$ & $27 \%$ & $18 \%$ & $7 \%$ \\
\hline Assertive ability & $13 \%$ & $30 \%$ & $28 \%$ & $19 \%$ & $10 \%$ \\
\hline $\begin{array}{l}\text { Elaboration of a plan } \\
\text { and its execution }\end{array}$ & $5 \%$ & $44 \%$ & $26 \%$ & $22 \%$ & $3 \%$ \\
\hline Praise himself & $20 \%$ & $30 \%$ & $32 \%$ & $13 \%$ & $5 \%$ \\
\hline Religion & $50 \%$ & $29 \%$ & $17 \%$ & $2 \%$ & $2 \%$ \\
\hline \multicolumn{6}{|c|}{ Coping reactions } \\
\hline Assertive ability & $13 \%$ & $30 \%$ & $28 \%$ & $19 \%$ & $10 \%$ \\
\hline $\begin{array}{l}\text { Elaboration of a plan } \\
\text { and its execution }\end{array}$ & $5 \%$ & $44 \%$ & $26 \%$ & $22 \%$ & $3 \%$ \\
\hline Praise yourself & $20 \%$ & $30 \%$ & $32 \%$ & $13 \%$ & $5 \%$ \\
\hline Religion & $50 \%$ & $29 \%$ & $17 \%$ & $2 \%$ & $2 \%$ \\
\hline $\begin{array}{l}\text { Search for information } \\
\text { about the situation }\end{array}$ & $8 \%$ & $19 \%$ & $47 \%$ & $22 \%$ & $4 \%$ \\
\hline $\begin{array}{ll}\text { Ventilation } & \text { and } \\
\text { Confidences } & \\
\end{array}$ & $13 \%$ & $27 \%$ & $38 \%$ & $17 \%$ & $5 \%$ \\
\hline
\end{tabular}

Tabla 1 SISCO instrument statistical percentages Source: Own Elaboration

We analyzed STAI results with descriptive statistics; table 2 shows the response percentage for each item with its respective indicator. Considering relevant aspects such as you are never calm, you have anxiety, disgust, upset, nerves, agitation, and bad thoughts.

\begin{tabular}{|l|r|r|r|r|r|}
\hline \multicolumn{1}{|c}{ Feeling } & Never & Sometimes & \multicolumn{1}{c|}{ Frequently } & \multicolumn{2}{c|}{$\begin{array}{c}\text { Almost } \\
\text { always }\end{array}$} \\
Calm & $48 \%$ & $26.7 \%$ & $29.4 \%$ & $32.4 \%$ & $6.4 \%$ \\
\hline Safety & $2.9 \%$ & $26.5 \%$ & $29.0 \%$ & $28.2 \%$ & $13.1 \%$ \\
\hline Tension & $10.6 \%$ & $51.2 \%$ & $23.4 \%$ & $10.6 \%$ & $3.9 \%$ \\
\hline Dislike & $19.8 \%$ & $54.6 \%$ & $16.7 \%$ & $6.6 \%$ & $2 \%$ \\
\hline Relaxed & $26.1 \%$ & $33.8 \%$ & $20.2 \%$ & $12.9 \%$ & $6.6 \%$ \\
\hline Disturbance & $31.5 \%$ & $44.7 \%$ & $14.6 \%$ & $6.0 \%$ & $2.9 \%$ \\
\hline Worry & $29.7 \%$ & $28.8 \%$ & $41.6 \%$ & $13.1 \%$ & $8.5 \%$ \\
\hline Satisfaction & $7.11 \%$ & $24.4 \%$ & $29.7 \%$ & $30.3 \%$ & $8.3 \%$ \\
\hline Afraid & $38.7 \%$ & $42.0 \%$ & $10.2 \%$ & $5.0 \%$ & $3.9 \%$ \\
\hline Comfort & $7.1 \%$ & $25.5 \%$ & $26.7 \%$ & $28.4 \%$ & $12.1 \%$ \\
\hline Confidence & $5.6 \%$ & $17.5 \%$ & $20.7 \%$ & $30.3 \%$ & $25.7 \%$ \\
\hline Nerves & $11.9 \%$ & $47.9 \%$ & $23.8 \%$ & $13.5 \%$ & $2.7 \%$ \\
\hline Agitation & $32.6 \%$ & $48.5 \%$ & $14.6 \%$ & $2.3 \%$ & $1.8 \%$ \\
\hline Indecision & $19.0 \%$ & $50.2 \%$ & $19.8 \%$ & $8.3 \%$ & $2.5 \%$ \\
\hline Tranquility & $5.2 \%$ & $24.0 \%$ & $28.6 \%$ & $28.0 \%$ & $14.0 \%$ \\
\hline Taste & $4.1 \%$ & $22.8 \%$ & $26.9 \%$ & $11.7 \%$ & $6.4 \%$ \\
\hline Worry & $16.7 \%$ & $49.5 .8 \%$ & $15.4 \%$ & $11.7 \%$ & $6.4 \%$ \\
\hline Stun & $38.0 \%$ & $38.9 \%$ & $13.8 \%$ & $5.8 \%$ & $3.3 \%$ \\
\hline Balance & $7.32 \%$ & $24 \%$ & $37.0 \%$ & $21.9 \%$ & $9.6 \%$ \\
\hline $\begin{array}{l}\text { Well-being in the } \\
\text { moment }\end{array}$ & $2.9 \%$ & $19.2 \%$ & $22.1 \%$ & $34.7 \%$ & $20.9 \%$ \\
\hline & & & & & \\
\hline
\end{tabular}

LOBATO-BAEZ, Mariana, MORALES-ROSALES, Luis Alberto, ALGREDO-BADILLO, Ignacio and RODRÍGUEZ-RANGEL, Héctor. Analysis of stress and anxiety in university students to identify correlated factors. Journal Educational Theory. 2021 


\begin{tabular}{|l|r|r|r|r|r|}
\hline $\begin{array}{l}\text { Well-being in } \\
\text { general }\end{array}$ & $5.4 \%$ & $18.8 \%$ & $23.2 \%$ & $34.5 \%$ & $17.9 \%$ \\
\hline Tiredness & $15.2 \%$ & $46.4 \%$ & $19 \%$ & $13.8 \%$ & $5.4 \%$ \\
\hline Agree with himself & $4.1 \%$ & $23.4 \%$ & $19.0 \%$ & $27.8 \%$ & $25.5 \%$ \\
\hline $\begin{array}{l}\text { Happiness like } \\
\text { others }\end{array}$ & $40.1 \%$ & $26.1 \%$ & $13.8 \%$ & $6.9 \%$ & $12.9 \%$ \\
\hline Fail & $17.5 \%$ & $47.6 \%$ & $15.2 \%$ & $12.1 \%$ & $7.3 \%$ \\
\hline Rest & $17.7 \%$ & $33.8 \%$ & $25.9 \%$ & $15.8 \%$ & $6.4 \%$ \\
\hline Tranquility & $9.20 \%$ & $20.2 \%$ & $23.0 \%$ & $26.7 \%$ & $20.7 \%$ \\
\hline Difficulty & $24.2 \%$ & $42.0 \%$ & $14.43 \%$ & $11.71 \%$ & $7.5 \%$ \\
\hline Worry & $29.2 \%$ & $32.6 \%$ & $19.4 \%$ & $11.0 \%$ & $7.5 \%$ \\
\hline General happiness & $7.5 \%$ & $14.2 \%$ & $15.2 \%$ & $31.7 \%$ & $31.1 \%$ \\
\hline Bad thoughts & $31.3 \%$ & $38.4 \%$ & $14.0 \%$ & $7.7 \%$ & $8.3 \%$ \\
\hline Lack of trust & $26.3 \%$ & $40.5 \%$ & $11.7 \%$ & $12.1 \%$ & $9.2 \%$ \\
\hline Safety & $6.4 \%$ & $28.2 \%$ & $25.3 \%$ & $23.6 \%$ & $16.3 \%$ \\
\hline Decision & $12.7 \%$ & $31.7 \%$ & $26.3 \%$ & $19.4 \%$ & $9.6 \%$ \\
\hline Out of place & $32.6 \%$ & $42.2 \%$ & $11.2 \%$ & $8.9 \%$ & $4.8 \%$ \\
\hline Satisfaction & $10.2 \%$ & $24.6 \%$ & $28.0 \%$ & $25.5 \%$ & $11.5 \%$ \\
\hline $\begin{array}{l}\text { Unimportant ideas } \\
\text { occupy your head }\end{array}$ & $20.7 \%$ & $40.7 \%$ & $18.8 \%$ & $11.71 \%$ & $7.9 \%$ \\
\hline Disappointments & $36.8 \%$ & $38.4 \%$ & $10.6 \%$ & $8.5 \%$ & $5.4 \%$ \\
\hline Stability and & $7.5 \%$ & $18.2 \%$ & $30.3 \%$ & $29.28 \%$ & $14.6 \%$ \\
\hline $\begin{array}{l}\text { Tension } \\
\text { nervousness from } \\
\text { thoughts }\end{array}$ & $24.2 \%$ & $41.2 \%$ & $15.4 \%$ & $11.7 \%$ & $7.3 \%$ \\
\hline & & & & & \\
\hline
\end{tabular}

Tabla 2 STAI instrument statistical percentages

\begin{tabular}{|c|c|c|c|c|c|}
\hline \multicolumn{6}{|c|}{$\begin{array}{l}\text { a) Non-standardized SISCO Multiple Linear Regression } \\
\text { Coeficieients }\end{array}$} \\
\hline Items & B & $\begin{array}{l}\text { Desv. } \\
\text { Error }\end{array}$ & Beta & $\mathbf{t}$ & Sig. \\
\hline P19 & 0.14 & 0.06 & 0.112 & 2.24 & 0.026 \\
\hline P26 & 0.15 & 0.05 & 0.151 & 3.17 & 0.002 \\
\hline P27 & 0.17 & 0.05 & 0.164 & 3.33 & 0.001 \\
\hline P29 & 0.16 & 0.05 & 0.166 & 3.01 & 0.003 \\
\hline N.A & N.A & N.A & N.A & N.A & N.A \\
\hline \multicolumn{6}{|c|}{$\begin{array}{l}\text { b) Non-standardized Multiple Linear Regression } \\
\text { Coefficients STAI }\end{array}$} \\
\hline Items & B & $\begin{array}{l}\text { Desv. } \\
\text { Error }\end{array}$ & Beta & $\mathbf{t}$ & Sig. \\
\hline P9 & 0.115 & 0.046 & 0.095 & 2.477 & 0.014 \\
\hline P25 & 0.133 & 0.044 & 0.126 & 3.02 & 0.003 \\
\hline P31 & 0.195 & 0.039 & 0.202 & 5.024 & 0 \\
\hline P37 & 0.225 & 0.044 & 0.222 & 5.095 & 0 \\
\hline P40 & 0.229 & 0.041 & 0.227 & 5.551 & 0 \\
\hline
\end{tabular}

Tabla 3 Non-standardized Multiple Linear Regression Coefficients

Source: Own Elaboration

\section{Multiple Linear Regression}

The Multiple Linear Regression method was applied to analyze the answers of 478 students; the model determined a value of 87.8 for the SISCO instrument and 58.5 for STAI. Once corrected for the sample effect, the values of the independent variable were 86.1 for SISCO and 54.8 for STAI. The standard error of the estimate (square root of the unexplained variable) was 87.8 and 58.5, respectively. By analyzing the SISCO instrument responses with Multiple Linear Regression, the most representative aspects were items P19, P26, P27, and P29 in Table 3a. These items correspond to concentration problems, aggressiveness feelings or increased irritability, praise for themselves, religion (prayers or attendance at mass), ventilation, and confidence (verbalization of the situation that worries).
The representative items were $\mathrm{P} 9, \mathrm{P} 25$, P31, P37, and P40 for the STAI instrument, see Table 3b. The results showed that students feel scared, tend to fail, and have bad thoughts. These are associated with some not revealing ideas that occupy your mind decreasing your performance or generating nervousness and tension.

\section{Pearson's correlation coefficient}

The correlation coefficient allows measuring the degree of correlation or association between two random variables (Águila, 2015 \& Macías, 2007).

In the present study, the highest correlations between variables were characterized, see Table 4. The interval of Pearson's correlation values was divided into three cases. Each case represents the values of the intervals to be considered for each type of correlation.

\begin{tabular}{|l|l|l|l|}
\hline \#Case & \multicolumn{2}{|c|}{ Interval } & \multicolumn{1}{c|}{ Meaning } \\
\hline 1 & 0.2 & 0.4 & Low positive correlation \\
\hline 2 & 0.4 & 0.7 & Moderate positive correlation \\
\hline 3 & 0.7 & 0.9 & High positive correlation \\
\hline
\end{tabular}

Tabla 4 Cases for the interpretation of Pearson's correlation

Source: Own Elaboration

\section{Results of the coefficients analysis}

The cases of the correlations were divided into a low positive correlation, moderate positive correlation, and high positive correlation. Tables 5 and 6 show the determination of the stressor associations variables from the CISCO and STAI measuring instruments.

Pearson SISCO correlation coefficient
\begin{tabular}{|l|l|l|l|l|l|}
\multicolumn{2}{|c|}{ p20 } & \multicolumn{2}{c|}{ p22 } & \multicolumn{2}{c|}{ p28 } \\
\hline p17 & $.722^{* *}$ & p17 & $.705^{* *}$ & p20 & $.724^{* *}$ \\
\hline p19 & $.728^{* *}$ & p19 & $.738^{* *}$ & p24 & $.730^{* *}$ \\
\hline p21 & $.753^{* *}$ & p20 & $.758^{* *}$ & p26 & $.758^{* *}$ \\
\hline p22 & $.758^{* *}$ & p21 & $.711^{* *}$ & p27 & $.773^{* *}$ \\
\hline p26 & $.715^{* *}$ & p23 & $.747^{* *}$ & p29 & $.796^{* *}$ \\
\hline p27 & $.718^{* *}$ & p29 & $.720^{* *}$ & NA & NA \\
\hline p28 & $.724^{* *}$ & NA & NA & NA & NA \\
\hline \multicolumn{2}{|c|}{ p29 } & \multicolumn{2}{|c|}{ p26 } & \multicolumn{2}{|c|}{ p27 } \\
\hline p22 & $.720^{* *}$ & p20 & $.715^{* *}$ & p20 & $.718^{* *}$ \\
\hline p24 & $.733^{* *}$ & p26 & $.716^{* *}$ & p25 & $.716^{* *}$ \\
\hline p26 & $.738^{* *}$ & p28 & $.773^{* *}$ & p27 & $.773^{* *}$ \\
\hline p27 & $.710^{* *}$ & p29 & $.710^{* *}$ & p28 & $.710^{* *}$ \\
\hline p28 & $.796^{* *}$ & NA & NA & p29 & $.815^{* *}$ \\
\hline NA & NA & NA & NA & N.A & N.A \\
\hline NA & NA & NA & NA & N.A & N.A \\
\hline
\end{tabular}

Tabla 5 Pearson SISCO correlation coefficient Source: Own Elaboration

LOBATO-BAEZ, Mariana, MORALES-ROSALES, Luis Alberto, ALGREDO-BADILLO, Ignacio and RODRÍGUEZ-RANGEL, Héctor Analysis of stress and anxiety in university students to identify correlated factors. Journal Educational Theory. 2021 


\begin{tabular}{|c|c|c|c|c|c|}
\hline \multicolumn{2}{|c|}{$\begin{array}{c}\text { Pearson S1 } \\
\text { p20 }\end{array}$} & \multicolumn{2}{|c|}{ p22 } & \multicolumn{2}{|c|}{ p28 } \\
\hline p17 & $722^{* * 8}$ & p17 & $705^{* *}$ & p20 & $.724^{*}$ \\
\hline 019 & $.728^{* *}$ & $\mathrm{p} 19$ & $738^{* *}$ & p24 & $.730^{* *}$ \\
\hline 021 & $.753^{* *}$ & p20 & $758^{* *}$ & p26 & .758 \\
\hline & $.758^{* *}$ & $\mathrm{p} 21$ & $711^{* *}$ & p27 & $.773^{\prime \prime}$ \\
\hline 26 & $.715^{* *}$ & $\mathrm{p} 23$ & $747^{* *}$ & p29 & .796 \\
\hline 227 & $.718^{* *}$ & p29 & $.720^{*}$ & NA & NA \\
\hline p28 & $.724^{* *}$ & NA & NA & NA & NA \\
\hline \multicolumn{2}{|c|}{ p29 } & \multicolumn{2}{|c|}{ p26 } & \\
\hline p22 & $.720^{* *}$ & p20 & $.715^{*}$ & p20 & $.718^{* *}$ \\
\hline 24 & $.733^{* *}$ & p26 & $.716^{* *}$ & p25 & $.716^{* *}$ \\
\hline p26 & $.738^{* *}$ & p28 & $.73^{* *}$ & p27 & $.773^{* *}$ \\
\hline p27 & $.710^{* *}$ & $\mathrm{p} 29$ & $.710^{*}$ & p28 & $.710^{*}$ \\
\hline p28 & $.796^{* *}$ & NA & NA & p29 & $.815^{*}$ \\
\hline$\sqrt{H}$ & NA & NA & $\mathrm{NA}$ & N.A & N.A \\
\hline $\mathrm{NA}$ & NA & NA & NA & N.A & N.A \\
\hline
\end{tabular}

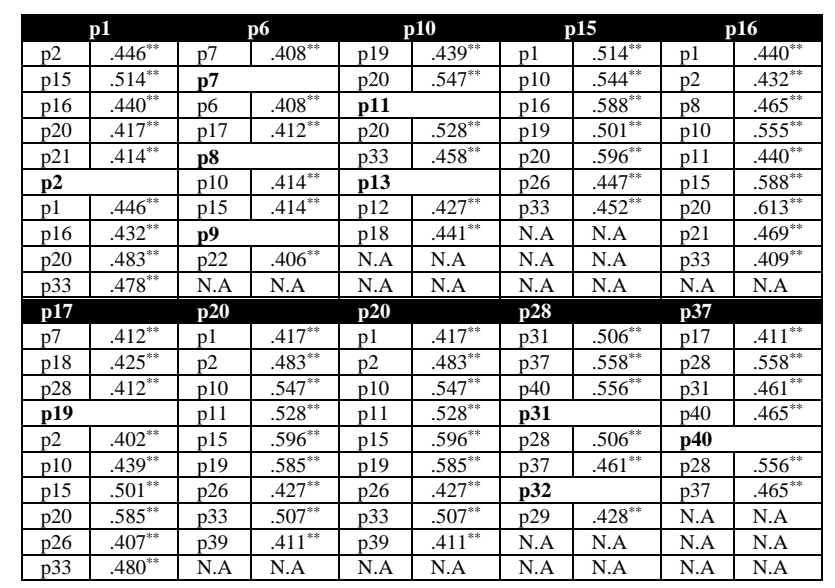

Tabla 6 Pearson STAI correlation coefficient Source: Own Elaboration

The SISCO instrument results concerning the values of the most representative correlations show the following:

1. Item $\mathrm{p} 20$, referring to conflicts or tendencies to argue or argue, correlates with ten items; such as anxiety, anguish or despair, aggressiveness feelings or increased irritability, isolation from others, reluctance to carry out schoolwork, elaboration of a plan and execution of his tasks, praise himself, religiosity (prayers and attendance at mass), ventilation and confidences (verbalization of the situation that worries).
2. Item $\mathrm{p} 22$, related to reluctance to do schoolwork, is correlated with anxiety, anguish or despair, feelings of aggressiveness or increased irritability, conflicts or tendencies to argue or argue, isolation from others, increase or reduction of food consumption, search for information on the situation of concern, ventilation and confidences (verbalization of the situation of concern).

3. Item p28, corresponding to religiosity (prayers or attendance at mass), correlates with conflicts or tendencies to argue or argue, assertive ability (defend preferences, ideas or feelings without harming others), elaboration of a plan and execution of his tasks, praise himself, search for information about the situation, ventilation, and confidences (verbalization of the situation that worries).

4. Item p29, referring to seeking information about the situation that worries, correlates with reluctance to carry out schoolwork, with assertive skills defending preferences, ideas or feelings without harming others, elaboration of a plan and execution of their tasks, praise himself, verbalization of the situation that worries.

5. Item p26, concerning to the preparation of a plan and execution of their tasks, has a correlation with conflicts or tendencies to argue or argue, religiosity (prayers or attendance at mass), search for information about the situation, ventilation and confidences (verbalization of the situation that worries).

6. Item p27, which refers to praise himself, is correlated with conflicts or tendencies to argue or argue, assertive abilities (defending preferences, ideas, or feelings without harming others), religiosity (prayers or attendance at mass), search for information about the situation.

The STAI instrument correlation results reveal the following: 
1. Item $\mathrm{p} 1$, referring to I feel calm, correlates with feelings of security, tranquility, pleasure, feeling good, safe, with a feeling of calm, I feel good, and I am happy.

2. Item p8, which corresponds to feel satisfied, is correlated with feeling comfortable and calm.

3. Item p9, corresponding to feel scared, is correlated with feeling nervous.

4. Item p10, referring to feeling comfortable, correlates with feeling balanced and feeling good.

5. Item p11, which corresponds to confidence in myself, is correlated with feeling good and safe.

6. Item p15, referring to feeling peaceful, is correlated with feeling calm, comfortable, pleasing, balanced, good, rested, and safe.

7. Item p16, corresponding to feeling comfortable, is correlated with feeling calm, safe, satisfied, comfortable, confident in myself, feeling calm, and feeling good.

8. Item $\mathrm{p} 17$, referring to I am worried, correlates with apprehension about some issues, stunned, and feeling that the difficulties are piling up and cannot overcome them.

9. Item p18, corresponding to feeling dazed, correlates with a feeling of agitation and worry.

10. Item p20 referring to feeling good correlates to feeling calm and confident in myself.

11. Item $\mathrm{p} 19$, referring to feeling balanced, is correlated with feeling safe, comfortable, calm, good, rested, safe, and a stable person.

12. Item $\mathrm{p} 28$, which refers to the fact that difficulties pile up and I cannot overcome them, correlate with I have bad thoughts, some unimportant ideas occupy my head and bother me when I think about the things I have in hand, I get nervous and tense.

13. Item $\mathrm{p} 31$, which refers to having bad thoughts, is correlated with I feel that difficulties pile up and I cannot overcome them. Some unimportant ideas occupy my head and bother me.

14. Item $\mathrm{p} 32$, corresponding to I lack confidence in myself, is correlated with worry too much about unimportant things.
15. Item p33, corresponding to feeling safe, confident in myself, calm, comfortable, good, happy, and a stable person.

16. Item $\mathrm{p} 37$, which corresponds to some unimportant ideas occupying my head, is related to I am worried, I feel that difficulties are piling up and I cannot overcome them, I have bad thoughts.

17. Item p40, referring to when I think about the things at hand I get nervous, it correlates with feeling that the difficulties pile up and I cannot overcome them, some unimportant ideas occupy my head and bother me.

\section{Discussion and Results}

This paper analyzed the level of stress, state anxiety, and academic trait presented by 478 higher-level students. The research aims are to carry out a correlation study to identify the main stressors, anxiety, physical, psychological, behavioral, and coping reactions of university students.

The results of the research indicate that students have psychological reactions to face aggressive feelings or irritability. Besides, they face them with praise themselves, search for information about situations, and elaborate a plan and its execution. We differ with the study of (Herrera, Betancourt, \& Camargo, 2013); they conclude that the students search for professional and social support, to a lesser extent, religion and autonomy.

Consequently, the results obtained highlighted that students cannot be calm and relax, having feelings of depression, sadness, anxiety, and anguish. Taking into account (Reyes, 2003), academic performance can be influenced by psychological variables of the individual and become, in turn, a stressor, especially for those with a low tolerance for frustration or failure in the assessment situations faced. It is evident that students feel scared and fail, having bad thoughts, some unimportant ideas occupy their head and bother them, they become nervous and tense. These findings differ from those of (Caballero, Abello \& Palacio, 2006, 2007), where exhaustion and cynicism, which negatively affect Self-efficacy, were determined as representative. 
We determined that most of the time, academic events that highlight stressors are the overload of tasks and work (exams, essays, research papers, etc.), limited time to perform the tasks, sleep disorders, chronic fatigue, and problems concentration. Other authors argue that exams are one of the fundamental academic stressors in students' daily lives (Barroza \& Silerio, 2007; Martín, 2007). In addition to the lack of time to carry out activities inherent to the academic field (Aranceli, 2006; Barroza \& Silerio, 2007) and the work of the courses (Aranceli, Perea, \& Ormeño, 2006).

Pearson's analysis of the STAI measurement instrument allows us to identify that the search for information about the situation of concern has a high correlation with reluctance to carry out schoolwork, assertive skills, defend preferences, ideas or feelings without harming others, making a plan and executing, praising yourself and verbalizing the situation of concern.

In addition to this, referring to self-praise is related to conflicts or tendencies to argue or discuss assertive skills (defending preferences, ideas, or feelings without harming others). In addition, students who praise themselves have a close relationship with religiosity (prayers or attendance at mass) because most students consider themselves believers in religion.

Consequently, we show that academic stress represents a severe problem at a higher educational level. On the other hand, it can be considered an opportunity for learning techniques to be strengthened to guide students to face future problems in their workplace.

Furthermore, the results indicate that a continuous evaluation of the behavioral level must be carried out to generate strategies that reduce stress. A subsequent correlation analysis between these results and academic performance is required to distinguish between stress that allows generating greater productivity and other that reflects a detriment to the student during their educational development.

Finally, it is essential to highlight that the results show increasing stress and anxiety as the semester progresses in their career. Hence, we need to offer students tools for their management.
If academic stress increases to severe levels, the students can develop diseases such as bruxism, anxiety, headaches, and ear pain. Future work will consider conducting segmented studies due to the peculiarities of the behavior of the student community when interacting with the society in which it operates, its family environment, and the beliefs it presents.

\section{References}

Alfonso Águila, B., Calcines Castillo, M., Monteagudo de la Guardia, R., \& Nieves Achon, Z. (2015). Estrés académico. Edumecentro, 7(2), 163-178.

Barraza Macías, A. (2006). Un modelo conceptual para el estudio del estrés académico. Revista electrónica de psicología iztacala, 9(3).

Caballero, C. (2006). Burnout, engagement y rendimiento académico entre estudiantes universitarios que trabajan y aquellos que no trabajan. Psicogente, 9(16).

Caballero, D., Cecilia, C., \& Palacio, S. (2007). Relación del burnout $\mathrm{y}$ el rendimiento académico con la satisfacción frente a los estudios en estudiantes universitarios. Avances en psicología latinoamericana, 25(2), 98-111.

Cabanach, R. G., Cervantes, R. F., Doniz, L. G., \& Rodríguez, C. F. (2010). Estresores académicos percibidos por estudiantes universitarios de ciencias de la salud. Fisioterapia, 32(4), 151-158.

Calvo, M. G. (1996). Ansiedad y deterioro cognitivo: incidencia en el rendimiento académico. Ansiedad y estrés, 2(2), 173-194.

Celis, J., Bustamante, M., Cabrera, D., Cabrera, M., Alarcón, W., \& Monge, E. (2001). Ansiedad y estrés académico en estudiantes de medicina humana del primer y sexto año. In Anales de la Facultad de Medicina (Vol. 62, No. 1, pp. 2530). Universidad Nacional Mayor de San Marcos.

Collazo, C., \& Rodríguez, Y. (2011). El estrés académico: una revisión crítica del concepto desde las ciencias de la educación. Revista Electrónica de Psicología Iztacala, 14(2), 1. 
Cevallos Trujillo, C. A. (2021). Análisis del impacto causado por el confinamiento durante la emergencia sanitaria por la enfermedad de COVID-19 en el desarrollo psicosocial de personas con trastornos de la conducta alimentaria.

Escandón-Nagel, N., Apablaza-Salazar, J., Novoa-Seguel, M., Osorio-Troncoso, B., \& Barrera-Herrera, A. (2021). Factores predictores asociados a conductas alimentarias de riesgo en universitarios chilenos. Nutrición Clínica y Dietética Hospitalaria, 41(2).

Fonseca-Pedrero, E., Paino, M., Sierra-Baigrie, S., Lemos-Giráldez, S., \& Muñiz, J. (2012). Propiedades psicométricas del Cuestionario de ansiedad estado-rasgo (STAI) en universitarios. Behavioral PsychologyPsicología Conductual, 20(3), 547-561.

Grös, D. F., Antony, M. M., Simms, L. J., \& McCabe, R. E. (2007). Psychometric properties of the State-Trait Inventory for Cognitive and Somatic Anxiety (STICSA): comparison to the State-Trait Anxiety Inventory (STAI). Psychological assessment, 19(4), 369.

Guadarrama, R., Márquez, O., Mendoza, S., Veytia, M., Serrano, J., \& Ruíz, J. (2012). Acontecimientos estresantes, una cuestión de salud en universitarios. Revista electrónica de psicología Iztacala, 15(4), 1532-1547.

Guillén-Riquelme, A., \& Buela-Casal, G. (2015). Estructura factorial del Cuestionario de Ansiedad Estado-Rasgo (STAI) para pacientes diagnosticados con depresión. Salud mental, 38(4), 293-298.

Herrera, N. L. B., Betancourt, L. K. S., \& Camargo, Y. S. (2013). Patrones de personalidad patológica y estrategias de afrontamiento en estudiantes de psicología. Psychologia. Avances de la disciplina, 7(2), 45-53.

Jara, D., Velarde, H., Gordillo, G., Guerra, G., León, I., Arroyo, C., \& Figueroa, M. (2008, September). Factores influyentes en el rendimiento académico de estudiantes del primer año de medicina. In Anales de la Facultad de Medicina (Vol. 69, No. 3, pp. 193-197). UNMSM. Facultad de Medicina.
Laredo, M. M. M., Huante, C. G. Á., Hernández, A. L., Moran, A. C. A., \& Loeza, B. M. L. (2014). Estrés académico en estudiantes. El caso de la Facultad de Enfermería de la Universidad Michoacana. Revista Iberoamericana de Producción Académica y Gestión Educativa, 1(1).

Lazarus, R. S., \& Folkman, S. (1986). Estrés y procesos cognitivos (No. 155.9042 L431e). Ed. Martínez-Roca.

Lezama, O. R. R., Ramos, R. A. E., Guerrero, M. C. P., González, A. S., \& Ávila, G. Á. (2021). Nivel de Afrontamiento al Estrés Académico de Estudiantes de la Licenciatura en Enfermería del Centro Universitario Valle de Chalco en el Periodo 2020. Revista Cubana de Enfermería, 37(1).

Lau, S. A. B., Paz, M. P., \& Martínez, R. O. (2006). Evaluación de niveles, situaciones generadoras y manifestaciones de estrés académico en alumnos de tercer y cuarto año de una Facultad de Estomatología. Revista Estomatológica Herediana, 16(1), 15-20.

Macías, A. B., \& Quiñónez, J. S. (2007). El estrés académico en los alumnos de educación media superior. Un estudio comparativo. Investigación Educativa Duranguense, (7), 4865 .

Macias, A. B. (2007). El Inventario SISCO del estrés académico. Investigación Educativa Duranguense, (7), 90-93.

Medina, M. E. G., \& Martínez, S. G. (2012). Estrés académico en el nivel medio superior. Revista en Ciencias Sociales y Humanidades Apoyadas por Tecnologías, 1(2).

Mendoza, L., Ortega, E. C., Quevedo, D. G., Martínez, R. M., Aguilar, E. J. P., \& Hernández, R. S. (2010). Factores que ocasionan estrés en Estudiantes Universitarios. Revista Ene de Enfermería, 4(3), 36-46.

Martín Monzón, I. (2007). Estrés académico en estudiantes universitarios Apuntes de Psicología, 25 (1), 87-99. 
Martínez-Otero Pérez, V. (2010). Sintomatología depresiva en universitarios: estudio de una muestra de alumnos de pedagogía. Revista Electrónica de Psicología Iztacala, 13(4).

Makaremi, A. (2000). Relation of depression and anxiety to personal and academic problems among Iranian college students. Psychological reports, 87(2), 693-698.

Organización Mundial de la Salud (2006). Departamento de Salud Mental y Abuso de Sustancias. Trastornos Mentales y Cerebrales. Prevención del Suicidio. Recurso para Consejeros.

Polo, A., López, J. M. H., \& Muñoz, C. P. (1996). Evaluación del estrés académico en estudiantes universitarios. Ansiedad y estrés, 2(2), 159-172.

Pottier, P., Hardouin, J. B., Dejoie, T., Bonnaud, A., Le Loupp, A. G., Planchon, B., \& LeBlanc, V. (2011). Stress responses in medical students in ambulatory and in-hospital patient consultations. Medical education, 45(7), 678687.

Putwain, D. W., Connors, L., Symes, W., \& Douglas-Osborn, E. (2012). Is academic buoyancy anything more than adaptive coping? Anxiety, Stress \& Coping, 25(3), 349358.

Reyes, Y. (2003). Relación entre el rendimiento académico, la ansiedad ante los exámenes, los rasgos de personalidad, el auto concepto y la asertividad en estudiantes del primer año de psicología de la UNMSM. Trabajo de grado no publicado, Universidad Nacional Mayor de San Marcos, San Marcos, Perú.

Sarason, I. G., Sarason, B. R., \& Pierce, G. R. (1990). Anxiety, cognitive interference, and performance. Journal of Social Behavior and Personality, 5(2), 1.

Sarubbi De Rearte, E., \& Castaldo, R. I. (2013). Factores causales del estrés en los estudiantes universitarios. In V Congreso Internacional de Investigación y Práctica Profesional en Psicología XX Jornadas de Investigación Noveno Encuentro de Investigadores en Psicología del MERCOSUR. Facultad de Psicología-Universidad de Buenos Aires.
Stöber, J. (2004). Dimensions of test anxiety: Relations to ways of coping with pre-exam anxiety and uncertainty. Anxiety, Stress \& Coping, 17(3), 213-226.

Venderbos, D., Van Den Bergh, C., Roobol, J., Schröder, H., Essink-Bot, L., Bangma H., et al. (2015). A longitudinal study on the impact of active surveillance for prostate cancer on anxiety and distress levels. Psycho-Oncology, 24(3), 348-354.

Zárate, N. E., Soto, M. G., Castro, M., \& Quintero, J. (2017). Estrés académico en estudiantes universitarios: medidas preventivas. Revista de la Alta Tecnología y la Sociedad, 9(4), 92-98. 